UDC 347:340.134(497.11:492)"18"

CERIF: H300

DOI: $10.5937 /$ AnaliPFB1804013A

Sima Avramović, $\mathrm{PhD}^{*}$

\title{
MIXTURE OF LEGAL IDENTITIES: CASE OF THE DUTCH (1838) AND THE SERBIAN CIVIL CODE $(1844)^{* *}$
}

The paper aims to examine the differences and similarities between the Dutch Civil Code of 1838 and the Serbian Civil Code of 1844. Although the historical circumstances of the two countries, their legal culture and their legal systems at the time of codification were significantly different, the author points to some similarities between their private law codes. Based on that comparison he distinguishes a more general problem of early modern codifications in the $19^{\text {th }}$ century, namely the issue of legal transfer's logic, causes and outcomes. Both in the cases of the Dutch and the Serbian codifications the predominant stereotype in literature are that they were more or less copies of the model codes (the French Code Civil of 1804 and the Austrian Civil Code of 1811, respectively). The author points out that only recently some diverse intonations started to appear on this matter, related to the two codifications. He stresses that in both cases legal borrowings were in many aspects inventive, innovative and influenced by a variety of other sources. The author based his conclusion on a comparative analysis of different legal identities present in the Dutch and Serbian codes. On that ground he revises the concept of mixed legal systems and suggests that mixture of legal identities should be more flexible, less demanding and open-ended notion.

Key words: Comparative legal traditions. - Legal transplants. - Legal transfer. - Mixed legal systems. - Private law codifications.

* Professor, University of Belgrade Faculty of Law, sima@ius.bg.ac.rs.

** I am particularly grateful to Tammo Wallinga from the Erasmus University Rotterdam and University Antwerpen and Martijn van der Burg from the Open University Amsterdam for their lectures at the University of Belgrade Faculty of Law in 2018 and 2016 respectively, for valuable discussions concerning the Dutch Civil Code of 1838, and help and advices in obtaining less available literature. 


\section{INTRODUCTORY REMARKS}

Legal development in the $19^{\text {th }}$ century was marked by remarkable civil codification movement all across Europe and by their subsequent legal borrowings all around the world. The "first generation" of modern private law codes originated in France (Code civil of 1804, hereinafter: $\mathrm{CC}$ ) and in Austria (Allgemeine bürgerliche Gesetzbuch für die gesamten deutschen Erbländer der Österreichen Monarchie of 1811, hereinafter: ABGB). ${ }^{1}$ Other European states decided to enact their own civil codifications much latter. Countries, nations and areas where either Napoleon or the Habsburgs were dominant usually applied the CC or ABGB in some form as their own codifications. This occurred not only due to military and political pressure by the mighty monarchies but also due to the immense prestige of the two civil codes. ${ }^{2}$ The reception of the $\mathrm{CC}$ was often connected with conviction that there was no better ratio scripta in civil law than the one enacted by the lawgivers in France, the cradle country of the natural law principles. Therefore in the first half of the $19^{\text {th }}$ century some countries (although still not many of them) took the $\mathrm{CC}$ for their own codification, with or without minor changes. The Austrian model was not so widely accepted but it still was quite influential within countries embraced by the Habsburg Monarchy rule or by its overall cultural influence. In any case, the first part of the $19^{\text {th }}$ century did

1 I use prefix "modern" to distinguish a few significant codes enacted before the $\mathrm{CC}$ and $\mathrm{ABGB}$ in the second half of the $18^{\text {th }}$ century, such as long-lasting Allgemeines Landrecht für die Preußischen Staaten of 1794 (often labeled as the Prussian Civil Code, hereinafter: ALR). It remained in force during the $19^{\text {th }}$ century in German states. But it was not a "modern" code: it had about 17.000 paragraphs and comprehended not only civil law but also parts of administrative, constitutional law and other legal issues. It reflected different kind of approach then modern civil codifications of $19^{\text {th }}$ century, tending to embrace the whole legal system in a written collection of legal norms.

W. Brauneder, "Europas erste Privatrechtskodifikation: Das Galizische bürgerliche Gesetzbuch", Naturrecht und Privatrechtskodifikation (Hrsg. H. Barta, R. Palme, W. Ingenhaeft), Wien 1999, 303-320 regards the Galizische bürgerliche Gesetzbuch of 1797 as the first private law code in Europe, prepared for the Austrian province Galicia in Poland. However, it was not more than a "preparatory" code for the ABGB, as witnessed by the same author in another article, W. Brauneder, "The 'first' European Codification of Private Law: the ABGB”, Zbornik Pravnog fakulteta u Zagrebu 63(5-6)/2013, 10191026. H. P. Glen, Legal Traditions of the World, Oxford University Press, Oxford 2007, 158 is decisive that the French civil code of 1804 denotes beginning of modern European civil identities.

2 A. Watson, Legal Transplants - An Approach to Comparative Law, The University of Georgia Press, Athens, Georgia 1993, 97. The author stresses that in general the most important cause for legal transplants is imposition of foreign law due to political power of the donor country or voluntary reception based on the authority of the donor system. His statement that legal transplants may sometimes happen by chance attracted significant criticism. 
not bring many more inventive civil codifications except the French and the Austrian model.

The next and the biggest wave of civil codifications took place quite a bit later, mainly during the second half of the $19^{\text {th }}$ century. The "second generation" of civil codes appeared when many countries decided to undertake the codification challenge. They mainly followed the prevailing French model and in very few cases the Austrian example. Many countries accepted heritage of the Romanistic Legal Family (e.g. certain Swiss cantons, Belgium in 1851, Italy and Romania in 1865, Portugal in 1867, Spain in 1889, Maghreb and some other African countries, countries in South and Central America, but also previously Louisiana in the USA and Quebec in Canada), while only some of them were influenced by the Germanic Legal Family tradition. ${ }^{3}$

At the beginning of the $20^{\text {th }}$ century "the third generation" of private law codifications arrived, having been inspired by the two most influential ones - the German Civil Code of 1896/1900 (Bürgerliches Gesetzbuch, hereinafter: BGB) and the Swiss Civil Code of 1907/1912 (Schweizerisches Zivilgesetzbuch, Code civil suisse, Codice civile svizzero, hereinafter: SZGB). Those two donor codes were followed by many recipient legal systems all across Europe and in other parts of the world.

Rare exceptions, appearing between the first and the second wave of private law codifications, already during the first half of the $19^{\text {th }}$ century, were presented in some Swiss cantons codes, the Dutch Civil Code of 1838 (Burgerlijk Wetboek, hereinafter: DCC) and the Civil Code for the Princedom of Serbia (Građanski zakonik za Kneževinu Srbiju), also known as the Serbian Civil Code of 1844 (hereinafter: SCC). Although they are often qualified more or less as copies of the French model (the DCC) or the Austrian model (the SCC), some different voices on his point started to appear relatively recently. Nobody denies the strong impact of the $\mathrm{CC}$ on the Dutch civil codification and decisive influence of the ABGB on the Serbian Civil Code. But more than a hundred years passed before scholars started to point to specific features of the Dutch and the Serbian civil codes, confirming that they were not mere replicas or shortened translations of the original codes, but that they had been much more innovative than usually perceived. The goal of this article is to make a parallel analysis of the two codes and check to what extent they were reproductions of their donor models, how much they represent a mixture of other sources and different legal identities, and what lessons theory of legal transfer and mixed legal systems may learn from these examples.

3 K. Zweigert, H. Kötz, An Introduction to Comparative Law (translated by T. Weir), Clarendon Press, Oxford 1998, 74-131, 132-179. 


\section{THE DUTCH CIVIL CODE OF 1838}

\subsection{Historical circumstances}

Although the DCC of 1838 was quite unique in early European private law codification (one could say it was the third creative civil code after the $\mathrm{CC}$ and the $\mathrm{ABGB}$ ) there are quite a few scholarly articles about it in more accessible languages. Literature about the DCC in Dutch language is also not as abundant as one might expect. ${ }^{4}$ Even the most comprehensive and representative book on Dutch law mentions the DCC of 1838 in a few sentences only. ${ }^{5}$

The Netherlands had a long legal tradition before the DCC appeared in 1838. This important legal heritage influenced later historical development of Dutch law, but it is usually quite neglected in terms of DCC evaluation. ${ }^{6}$ The reason is probably the general impression that the CC was predominant basis for the DCC and that the Dutch law as a whole was strongly influenced by French law when Napoleon imposed the CC on the Netherlands. However, since the glorious Dutch Revolt and formation of the United Dutch provinces within the Dutch Republic, in the $16^{\text {th }}$ and $17^{\text {th }}$ centuries, various local systems of customary law flourished. Owing to the tremendous development of legal doctrine and theory, particularly to a great contribution of Hugo Grotius (1583-1645), as well as to later works of Jochannes Vout, Ulrik Huber and their comments of the Justinian codification, a specific mixture of traditional custom and Roman law became known as Roman-Dutch law. ${ }^{7}$

However, during the French Revolution the Batavian Republic was established in the Netherlands (1795-1806). As a result of the enthusiastic

4 One of the rare examples is G. Meijer, S. Y. Th. Meijer, "The Influence of the Code Civil in the Netherlands", European Journal of Law and Economics 14(3)/2002, 227-236. They quote only a few texts in Dutch about the DCC. The second more detailed contribution is J. Lokin, "Die Rezeption des Code Civil in den nördlichen Niederlanden", Zeitschrift fur Europaisches Privatrecht 4/2004, 932-946. There is also a short but instructive text: A. Fontein, "A Century of Codification in Holland", Journal of Comparative Legislation and International Law 21(3)/1939, 83-88.

5 J. Chorus, P. H. Gerver, E. Hondius, Introduction to Dutch Law, Kluwer Law International, Alphen aan den Rijn 2006, 14.

6 An important exception is the contribution by historian M. van der Burg, "Cultural and Legal Transfer in Napoleonic Europe: Codification of Dutch Civil Law as a Cross-national Process", Comparative Legal History 3/2015, 92.

7 R. Feenstra, R. Zimmermann (eds.), Das römisch-holländische Recht: Fortschritte des Zivilrechts im 17. und 18. Jahrhundert, Duncker \& Humblot, Berlin 1992; G. C. J. J. van den Bergh, Die holländische elegante Schule: Ein Beitrag zur Geschichte von Humanismus und Rechtswissenschaft in den Niederlanden 1500-1800, Klostermann, Frankfurt 2002; S. Avramović, V. Stanimirović, Uporedna pravna tradicija, Pravni fakultet Univerziteta u Beogradu, Beograd 2015, 253-4. 
and widespread support of the Dutch people for the French Revolution, it was installed as a "sister-republic" of France instead of the old Dutch Republic. The idea of the Dutch law codification was born soon and the first attempt to codify Dutch civil law appeared in 1798. The Amsterdam law professor Hendrik Constantijn Cras presided over the Drafting Commission. He rapidly prepared a draft which combined natural law, Roman law and customary law. ${ }^{8}$ However, in 1800 Napoleon formed the Commission of four distinguished French lawyers (Jean-Étienne-Marie Portalis, Jacques de Maleville, Félix-Julien- Jean Bigot de Préameneu and François Denis Tronchet) and quite promptly enacted in March 1804 his famous French Civil Code, known also as Code Napoléon since 1807.

About the same time, at the political level, a monarchy was formed in 1806, the Kingdom of Holland, instead of the "sister-republic", and ruled by Napoleon's brother, Louis Bonaparte, who became the first modern monarch of the Netherlands. He asked Johannes van der Linden, secretary of Cras' Drafting Commission, to prepare a civil code for the new kingdom. Van der Linden was deeply impressed by Pothier and translated several his works, among them Traité des Obligations. ${ }^{9}$ But he was hesitant to accept Roman law, as well as "unsure and diverging" local customary law. He also rejected many parts of Cras' previous project code and of the $\mathrm{CC}$, therefore the outcome was "a remarkable legal mixture". ${ }^{10}$ However, Napoleon wanted to impose the CC to the small country of 1.8 million inhabitants "who do not need a separate legal system", and ordered his brother to obtain a Dutch translation of the CC with some limited adaptations. Although Dutch lawyers and the people highly respected French law and the CC, they were eager to preserve their institutions and customs. However, Louis Napoleon appointed a lawyer from Rotterdam, Arnold van Gennep, as the president of the new commission. Quite quickly, 1 on May 1809 the code was adopted by royal decree as the Wetboek Napoléon, ingerigt voor het Koningrijk Holland [Code Napoléon Fitted up for the Kingdom of Holland], and Roman-Dutch law was mostly put aside. Van Gennep succeeded in including in the Code certain important adjustments, particularly in family law. Consequently, the Code of 1809 was basically the CC with some alterations and limited changes, but it remained an important piece of heritage for future Dutch private law development. It was particularly important in strengthening the opinion that civil codification is a necessary means to express and maintain national identity.

8 M. van der Burg, 96. For information about the history of the Dutch civil law before the DCC of 1838, see J. Lokin, 932-943.

9 G. Meijer, S. Y. Th. Meijer, 229.

10 M. van der Burg, 98. 
The Code of 1809 did not last for long. Napoleon annexed the Netherlands in 1810 (the so-called Réunion à l'empire), and it became a part of the centralized state, legal system and codification. After Napoleon's military defeat in 1813, when Dutch independence was restored, the private law codification impetus survived. The path for the new codification was politically, psychologically and professionally paved. However, many old controversies still remained and some new problems appeared.

\subsection{A winding road towards the new Civil Code of 1838}

The new independent state of the Netherlands was established by the Constitution of March 1814. In Article 100 it prescribed that civil codification is necessary. However, Article 2 of the revised Constitution, of August 1815, set up that all laws of the existing legal order remained valid. In that way French law was "Netherlandized" and vice-versa. ${ }^{11}$ The new drafting commission was formed already the following month. It included three members who had previously prepared the Code Napoléon Fitted up for the Kingdom of Holland of 1809, and they took it as a basis for their new endeavor. One of the members, J.M. Kemper, who was Cras' pupil, was against that approach, having been dissatisfied with strong impact of the $\mathrm{CC}$ on the previous code. So the old idea about the code based predominantly on the old Dutch law was revived. ${ }^{12}$

In addition to initial disagreements in the Drafting Commission, a new political development complicated the issue even further. According to the Vienna Congress of 1815 the Northern and Southern regions were united in the Kingdom of the Netherlands, with Willem I as king. This brought about a new issues of discrepancies between the legal traditions of the North and South, as these regions had developed quite separately. ${ }^{13}$ Kemper was inclined to the Northern legal tradition and the solutions following that direction, while the initiatives of the Southern (later Belgium) were against it and favored the French CC. It was more than a decade before the new draft was adopted by the Parliament, in 1830 . However general dissatisfaction in the Southern provinces exploded that same year in the so-called Belgian Revolution, demanding secession of the south provinces. The conflicts and political provisorium lasted until 1839 , when the Netherlands finally recognized the Belgian state. ${ }^{14}$

11 J. Lokin, 939.

12 G. Meijer, S. Y. Th. Meijer, 230. A. Héroguel, Problèmes de traductions dans les droits civils français et néerlandais, L' Harmattan 2000, 81-82.

13 On political development in that period: M. Lok, M. van der Burg, "The Dutch Case: The Kingdom of Holland and the Imperial Departments", The Napoleonic empire and the new European political culture (eds. M. Broers, P. Hick. A. Guimerá), Palgrave Macmillan, Basingstoke 2012.

14 G. Meijer, S. Y. Th. Meijer, 230. 
In the meantime, according to the 1815 Constitution, Frenchinfluenced civil law remained in force in the Netherlands. Finally, after all turbulences, the DCC was introduced in 1838, when the Netherlands finally acquired its final territorial and national profile. The struggle between the French pattern and national-influenced code was resolved in such a way that the $\mathrm{CC}$ influence strongly prevailed, mixed with some elements of the national customary law and Roman law traditions. ${ }^{15} \mathrm{~A}$ proper introduction to the rest of our research is statement that the DCC of 1838 "shows all good and bad sides of a copy of the masterpiece."16

\section{THE SERBIAN CIVIL CODE OF 1844}

\subsection{Literature and destiny of the SCC}

As was the case with the DCC, the Serbian Civil Code of 1844 was quite neglected in literature in non-native languages and it remained nearly unknown to foreign researchers. It was only quite recently that a more extensive contribution on the SCC appeared in English, within a Max-Planck Institute project,. ${ }^{17}$

The dominant attitude in Serbian literature, both older and contemporary, is one of much criticism and disparaging the qualities of the SCC. The first wave of criticism came soon after its enactment and was mostly based on the objection that it unsuccessfully and hugely accepted the ABGB. However, part of attacks was directed personally against Jovan Hadžić who drafted the SCC, due to his conservative approach in actual linguistic reform and his conflicts with prominent and influential Serbian language reformer Vuk Karadžić. ${ }^{18}$

The second torrent of unfavorable comments was even stronger. It was launched by prestigious Serbian legal scholars in the first decades of the $20^{\text {th }}$ century when the need arose to revise the SCC or to create a new one. By this time the SCC was more than 60 years old and when a new

15 Ibid.

16 P. Scholten, Mr. C. Asser's Handleiding tot de beoefening van het Nederlandsch Burgerlijk Recht, Kluwer Law International, 1974³ 177 (according J. von Lokin, 41).

17 S. Avramović, "The Serbian Civil Code of 1844: a Battleground of Legal Traditions", Konflikt und Koexistenz. Die Rechtsordnungen im 19. und 20. Jahrhundert, Band II - Serbien, Bosnien-Herzegowina, Albanien (Hrsg. Th. Simon), Max-PlanckInstitut für europäische Rechtsgeschichte, Frankfurt am Main 2017, 379-482. There were only a few very short informative articles in foreign languages, mostly lacking profound analysis, ibid., 381, n.7.

18 P. Šeroglić, "Pregled Zakonika Gradjanskog za knjaževstvo Serbiju, 25. marta 1844. obnarodovanog”, Bačka vila 4/1845, 114-187; D. Matić, Objasnenija Građanskog zakonika za knjaževstvo Srbsko, I-III, Beograd 1850-51. See also S. Avramović (2017), 88-89. 
modern generation of civil codes was enacted (the German BGB and Swiss SZGB). The SCC was also surpassed in some issues by modern developments, but some old sensible issues also were reopened, such as unfavorable legal position of women and dissolution of the large communitarian families (porodična zadruga in Slavic terminology). However, the political will, determination and adequate academic courage for more radical changes were missing. The commission for revise the SCC was formed in 1909 and never completed their task. The SCC was blamed for all shortcomings of the civil law legislation. The worst qualification was that "our Civil Code is a first-class legal curio, with so many unclear notions, without a system, with a lack of precise terms, that it represents a real disgrace for the legal community of Serbia."19 Very influential was also the observation by authoritative Serbian legal scholar and historian Slobodan Jovanović, who said that Jovan Hadžić "appears only as a well-educated copyist", and that the SCC is abridged edition of the ABGB. ${ }^{20}$

However, World War I thwarted further legal reforms. One of the results of the War was the formation of a new united state, called the Kingdom of Serbs, Croats and Slovenians (Kingdom of Yugoslavia from 1929) instead of the former Kingdom of Serbia. Similarly as in the Netherlands after 1830, the issue of different national legal traditions complicated attempts to enact a new civil code. Different parts of the country belonged to diverse legal heritages, so the SCC remained valid predominantly in Serbia. The Drafting Commission for preparing the unified civil codification was formed in 1930 and the criticism of the SCC in literature was nearly unanimous. It became quite outdated as it was not seriously innovated for nearly an entire century. Scholars were divided between several solutions, including the idea the that new codification should follow model of the General Property Code for the Principality of Montenegro of 1888, written by a prominent follower of the historical school, Valtazar Bogišić, who had included much of the national customary law. ${ }^{21}$ However, prevailing attitude was that the

19 D. Aranđelović, Rasprave iz privatnog prava, Beograd 1913, 145, n.10 (translated by the author). D. Aranđelović, "O izmeni našeg Građanskog zakonika", Branič 9(1)/1904, 449 also states that "our Civil Code is the worst of all codes ever issued in liberated Serbia. The issues that it regulates are so endangered by legislative ambiguity and numerous loopholes, that a new, good civil code is our necessity."

20 S. Jovanović, "Jovan Hadžić", Iz naše istorije i književnosti, Srpska književna zadruga, Beograd 1931, 45.

21 M. Konstantinović, "Jugoslovenski građanski zakonik", Anali Pravnog fakulteta u Beogradu 3-4/1982, 384-396 (republished from Pravni zbornik 1(2-3)/1933). More on drafting private law codification in Montenegro, M. Luković, "Valtazar Bogišić and the General Property Code for the Principality of Montenegro: Domestic and Foreign Associates", Balcanica 39/2008, 175-188. See also multilingual collection of papers in 
ABGB should remain the model code. A great discussion followed and it lasted till World War II.

Consequently the SCC survived for several more years. However, after World War II, in 1946, the new Communist regime of the Federative People's Republic of Yugoslavia enacted the law prescribing that legislation from the "capitalist" period, including the SCC, was to be rescinded. As it was impossible to reform the civil law in a short time, the same law allowed legal principles from previous legislation to be applied if they did not contravene constitutional principles, actual provisions and socialist ethics. Nonetheless, the pre-communist legislation could not be regarded as a source of law or be quoted as such. Thus the principles of the SCC can still be used and quoted in court decisions today, in cases of gaps or a lack of clarity in current legislation, but this happens very rarely. ${ }^{22}$

\subsection{The complicated pregnancy and difficult birth of the SCC}

The Serbian state and law were born as early as the $13^{\text {th }}$ century. Stefan Nemanja was founder of the Medieval Serbian dynasty, and his oldest son Stefan became the Grand Prince of Serbia in 1196, whilst in 1217 he received the royal title from the Pope, therefore called Stefan the First-Crowned. The youngest son of Stefan Nemanja, Rastko (ordained Sava), in 1219 obtained recognition of the Serbian Orthodox Church from the Patriarch of Nicaea and he received the title of Archbishop. That same year he created a voluminous codification called Zakonopravilo or Nomocanon (later known as Krmčija, when it was used in Bulgaria, Romania and Russia). It was a combination of church and civil norms, mostly influenced by Byzantine law, adapted to Serbian societal needs and in some cases influenced by elements of national customary law. The Nomocanon of St. Sava was written in folk language and was composed of 70 extensive chapters, covering around 400 pages. It remained in use in Serbia all through the Middle Ages, ${ }^{23}$ even when the country fell under Ottoman rule, in the $15^{\text {th }}$ century.

Serbia gained autonomy through a rebellion in 1804, commonly referred to as the First Serbian Uprising or the Serbian Revolution, led by Karađorđe (Black George), founder of the Karađorđević dynasty. ${ }^{24}$ Since

two volumes dedicated to the hundredth anniversary of Bogišić's death, Breneselović, L. (ed.), Spomenica Valtazara Bogišića, I-II, Službeni glasnik, Beograd 2011.

22 More: S. Avramović (2017), 465.

23 Nomocanon of St. Sava was used within the Serbian Orthodox Church as the chief source of law during the Middle Ages but parts of it are still in use today. Some norms from the Nomocanon were also included in the SCC.

24 This term is attributed to German historiographer Leopold von Ranke according to the title of his book Die Serbische Revolution published in 1829, English translation: 
then the nation-building process was developed rapidly. When the First Serbian Uprising was crushed in 1813, the Second Uprising in 1815, led by Miloš Obrenović marked continuation of the Serbian Revolution and enabled Serbia to function as a liberated, de facto independent principality. It was normatively fixed in $1830 \mathrm{~s}$ in few documents issued by the Ottoman Porte, which recognized Serbia's complete internal independence in legislative, executive and judiciary matters, including recognition of the hereditary dynasty of Prince Miloš Obrenović. He was aware that the development of national legal system is an important part of comprehensive independence and at his initiative the first Serbian constitution was enacted in $1835 .^{25}$

Prince Miloš also wanted to produce a civil code for the young country as token and proof that it deserves not only autonomy but full independence. Already in 1829 he ordered his son's teacher, Georgios Zachariades, to translate the $\mathrm{CC}$, which was the most popular donor code at the time. However it was a very bad translation: Zachariades did not know Serbian very well, French was not his preferred language, so he used the German translation of the CC and, above all - he was not a lawyer. That same year Prince Miloš formed a parallel drafting commission with the same task. It consisted of Vuk Karadžić, an educated language scholar with a European background and great reputation, Archpriest Mateja Nenadović, the author of the first Serbian legal text during the First Serbian Uprising, three political leaders and an administrative officer. However, they too used the German translation of the CC since the members of the Commission were more familiar with that language. ${ }^{26}$ The entire endeavor slowed down. In 1834 Prince Miloš received a section of the $\mathrm{CC}$ and found that the translation was quite poor. $\mathrm{He}$ changed the drafting Commission and involved his secretary, Dimitrije Davidović, who was a polyglot, and also knew French. In a letter to the Commission dated April 1834, Davidović stated for the first time that the ABGB was shorter and more intelligible. He advised the Commission to compare the Austrian provisions to those translated from French, and to take from the two codes the shorter and more comprehensible formulations. It was too demanding and complicated a job for the Commission. Prince Miloš understood that the internal Serbian professional capacities were not sufficient to prepare an appropriate codification project.

Leopold Ranke, A History of Serbia and the Serbian Revolution (transl. A. Kerr), J. Murray, London 1847.

25 S. Avramović, "Sretenjski ustav - 175 godina posle", Anali Pravnog fakulteta u Beogradu 1/2010, 36-65.

26 There are traces in the literature on grotesque failures in translating some legal terms. More about the problems with Zachariades and the Commission in 1929, see S. Avramović (2017), 390-395. 
The Prince made a radical move and in 1836/7 invited two distinguished Serbian lawyers from Novi Sad, which was then a part of the Austrian Empire, to help codifying the law in Serbia. ${ }^{27}$ After initial joint efforts, Vasilije Lazarević became in charge of the criminal code, while Jovan Hadžić, who was also a distinguished writer and linguist, dealt with the civil law codification. He had studied law in Vienna and acquired his doctor iuris title from the University of Pest in 1826. He was also a practicing lawyer in Novi Sad and a city senator. His initial task was to check the $\mathrm{CC}$ translation and suggest improvements to it. However, from the very beginning Hadžić was inclining to the Austrian legal tradition, which can easily be explained by his cultural profile, professional orientation, as well as pragmatic and political reasons. ${ }^{28}$ Prince Miloš was not strongly opposed to that initiative, particularly as he probably had in mind the importance of commercial and political connections with Austria. He was also informed that the ABGB was about one thousand articles shorter than the $\mathrm{CC}$ and that it could be adapted more easily and quickly.

Prince Miloš warned Hadžić that he would encounter at least two hot issues: inheritance rights and legal position of women, as well as complicated landed property customary law and organization of the family. In other words, the choice was not only between French and Austrian model codes, but also between the old and the modern legal traditions. Those circumstances held up the codification activities yet again. The political situation in the country caused additional delay. Prince Miloš abdicated in 1839 as he was dissatisfied with the new Constitution of 1838, which limited his authority. After a short rule of his second son, young prince Michael, the Obrenović dynasty was overthrown by the old powerful Serbian politicians in 1842. The Karađorđević dynasty came into power, represented by the politically quite weak Prince Alexander. The State Council, a collective body of old politicians, became the actual chief political authority. ${ }^{29}$ The political change gave new momentum to the codification and facilitated the switch to the ABGB as the model code. The draft of the SCC was soon prepared. The Council became in charge of its analysis and acceptance, particularly on the most sensitive issues. So the State Council changed articles 396 and 397,

27 Many Serbs inhabited Habsburg Monarchy north of the Sava and Danube rivers, particularly during the first Great Migration of Serbs in 1690. It was result of cruelties carried out by the Turks, in revenge for the Serbs siding with the Habsburg Monarchy against Ottoman forces during their long conflict in the Balkans in the $17^{\text {th }}$ century. The Austrian Emperor granted more than 37.000 Serbian families the right to territorial autonomy within a separate voivodeship (province), which was named Voivodina in 1848 .

28 Ibid., 398-400.

29 Ibid., 404-410. 
contrary to Hadžić's proposal and will, giving priority to sons over daughters in inheritance according the customary law. Also, the final solution of Article 920 was that married women were considered equal to minors in their legal capacity during the lifetime of their husbands. With those and some other changes, the SCC was adopted in March 1844, having been mostly influenced by the ABGB as opposed to the CC. However, it contains quite many different solutions and influences of various legal traditions (including some solutions from the CC), so it should not be qualified as a mere copy or a shortened translation of the $\mathrm{ABGB}$. The following analysis will attempt to offer argumentation that both the DCC and the SCC were much more original and inventive than it is commonly recognized.

\section{THE DUTCH AND SERBIAN CIVIL CODE: LEGAL REPLICAS OR CREATIVE ASSORTMENT?}

The cliché in scholarly literature and in academic manuals is that the DCC is replica of the $\mathrm{CC}$, while the SCC has an even worse reputation of being an unsuccessful translation of the ABGB. However, there are many more discrepancies between the donor codes and the two recipients than usually observed. We will examine first the case of the DCC and then of the SCC.

\subsection{Variances between the DCC and the CC}

In their analysis whether the DCC should be regarded as a copy of the CC or not, Gerrit Meijer and Sjoerd Meijer focused on the form, structure and content of the donor and the recipient codes ${ }^{30}$ For the sake of easier comparison the same approach will be followed in analysis of the SCC and ABGB relationship.

\subsubsection{Form and structure of the DCC and CC}

G. Meijer and S.Y.Th. Meijer stress that the DCC basically follows the pattern applied in the CC. However they attest that the layout of the DCC is not directly based on the CC and that the DCC is more based on the Kemper's Commission's proposal of 1820. It abandoned a lot of the French influence but was not accepted by the Parliament, mostly due to political reasons and relationship between Northern and Southern parts. But in 1838, when Belgium separated, the Northern approach was again a bit more reluctant in accepting the $\mathrm{CC}$ model as a whole.

30 G. Meijer, S. Y. Th. Meijer, 232. 
The most visible formal difference is that the $\mathrm{CC}$ is divided into three books, while the DCC has four, the allocation of titles and legal institutions of the second and third book is often different, etc. ${ }^{31}$ Above all, the DCC is shorter, containing 2,030 articles as opposed to the CC's 2,281 .

Although it mostly follows Justinian's Institutions structure, the DCC favors strict differentiation between real rights (ius in rem) and personal rights (ius in personam), which was not applied in the CC, where the right of property plays a central role. Detailed analyses of the differences, particularly regarding the law of property and obligations, were described in detail long ago, but only in Dutch language. ${ }^{32}$ Despite of many diversions, the DCC is still strongly influenced by the CC in form.

\subsubsection{Diversities in content of the DCC and CC}

There are many more specific features considering different institutions and details between the two codes than in their form. Meijers extract a few elements to illustrate the DCC specific features.

\subsubsection{Omitted institutions}

Some institutions typical for the CC do not exist in the DCC, such as the institution of civil death, rooted in the political development of French Revolution, which is absent, as quite odd to the Dutch society. The DCC also avoided the institution of acte respectieux (act of respect) which existed in the $\mathrm{CC}$, requiring consent of the father in cases when a bridegroom was younger than 25 , although he had reached general majority age of 21 (in case of the bride no consent of parents was necessary if she had reached general majority age). Another example was conseil judiciaire (counsel for intellectually limited persons) regarding persons who could be subjected by the first level courts to a kind of custody of another person or group of persons. Such a person could not conclude particular contracts on the grounds of their intellectual limits but would be capable of undertaking other legal acts or contracts. It was not accepted in the DCC due to differences in legal and social perceptions. Some institutions were misplaced from the $\mathrm{CC}$ model as in the meantime they were eliminated from the French legislation itself in following decades after the CC was adopted, such as tutor ad hoc (guardian for an occasion).

31 A. Héroguel, 85-87.

32 C. Asser, Het Nederlandsch Burgerlijk Wetboek vergeleken met het Wetboek Napoleon, De Gebroeders van Cleef, 's Gravenhage 1838; J. van Kan, "Het Burgerlijk Wetboek en de Code Civil", Gedenkboek Burgerlijk Wetboek 1838-1938 (ed. P. Scholten, E. M. Meijers), Tjeenk Willink, Zwolle 1938, 243-276. 


\subsubsection{Former law additives}

According to G. Meijer and S.Y.Th. Meijer, some national rules served as supplements to the provisions of the CC or were inserted instead of the French legal concepts. The most prominent example is the deed of transfer in public registers, as a condition for transfer of ownership of immovable property, which was not necessary in the French law. Dutch drafters were of opinion that ownership on immovable property can only be transferred by evidence in public registers. Due to Roman-Dutch law way of thinking, real rights like the long lease of land and the right of superficies are included in the DCC, although they did not exist in the CC. Also the DCC is different from the French provisions in mortgage priority rights, the right of pledge with regard to preferred debts, ${ }^{33}$ considering hypothec, etc. There are also some particular institutions that exist in the DCC although they were not present in the CC, but those instances are not very frequent.

\subsubsection{Common French and Dutch legal heritage}

The Dutch scholars who oppose the stereotype that the DCC is mainly a copy of the $\mathrm{CC}$ rightly stress that both legal traditions were deeply influenced by Roman law and some other shared roots. This may reinforce the impression that the DCC is completely influenced by the $\mathrm{CC}$, even though basically both legal systems are influenced by the same predecessors. There are at least a few important common origins of the French and the Dutch legal traditions which provide a common legal heritage.

Roman law unquestionably forms a universal common legal tradition of the European countries and of the continental civil law legal systems. ${ }^{34}$ The only issue might be whether Roman law principles arrived in recipient codes directly or by transfer from donor codes. That topic will be also examined in the next chapter of this article (4.2.2.2.). Roman law of the CC strongly affected the DCC law of obligations and law of property, while it had less influence on family law.

Canon law was an important element of ius commune during medieval times throughout Western Europe, including France and the Netherlands. Canon law rules influenced family law more than other fields. Meijers specifies the solemnization of a marriage as one of the examples that did not infringe on former Dutch law. Civil marriage as the only valid form of marriage was the heritage of the French Revolution and religious marriage became secondary, with no legal effect.

33 G. Meijer, S. Y. Th. Meijer, 233; A. Héroguel, 91.

34 Among the most convincing and influential books on that topic: R. Zimmermann, The Law of Obligations: Roman Foundations of the Civilian Tradition, Oxford University Press, Oxford 1996. 
Customary law was different in many regions, territories and cities even within the same country during medieval times, as ius proprium but the advantages of a written law (particularly in the pays de droit écrit in France), activity of the courts and legislation modified it throughout Europe in the direction of common customary law. ${ }^{35}$ In case of France and the Netherlands, early customary law of the German tribes, especially of the Franks, played an important role in their development. Examples of customary law origins are particularly present in the law of inheritance and the law of matrimonial property, such as in cases of ante-nuptial or post-nuptial agreements and the direct succession of heirs. ${ }^{36}$

French legal concepts were also a part of Dutch traditions, particularly during the period of Napoleonic influence, but also during the French Revolution. This enabled an easy and comfortable legal transfer which was not, in many points, regarded as a French influence but was accepted as a part of Dutch legal tradition. In other words, the issue of drafting the DCC was not which code would be selected as the model; it was only controversial how many and in which sectors genuine Dutch legal tradition would be included in the codification.

In any case, although impact of the $\mathrm{CC}$ was increasing, due to certain distinctive features it would not be adequate to treat the DCC just as a copy of the French model code.

\subsection{The $\mathrm{SCC}$ relation towards the $\mathrm{ABGB}$}

The birth of the SCC was very different from the DCC rise; the road towards civil codification in the $19^{\text {th }}$ century Serbia was more complicated. The country was just undergoing revival after the longlasting Ottoman rule, the state was in the process of transition from autonomous status towards full independence, society was lacking refined intellectuals, the educational institutions had just started functioning, customary law was widely applied, the judiciary was still quite immature, and idea of civil law codification was rudimentary. Nevertheless, due to the clear vision of Prince Miloš that a developed legal system is precondition for national identity and sovereignty building, Serbia received its first constitution in 1835 and its private law codification already in 1844 .

After several years lost in searching the the most proper donor code, the SCC was finally shaped according to the ABGB model. However, as well as in case of the DCC, there were certain different features important in defining the degree of borrowing.

35 O. F. Robinson et al., European Legal History: Sources and Institutions, Oxford University Press, Oxford 2005, 107-115.

36 G. Meijer, S. Y. Th. Meijer, 235. 


\subsubsection{Form and structure of the SCC in comparison with the $A B G B$}

Differences in form and structure between the SCC and ABGB are even more remarkable than in case of the DCC French borrowings.

\subsubsection{Size of the Code}

The first impression is an amazing discrepancy in volumes: the ABGB consists of 1502 articles while the SCC has only 950 . The SCC was one of the briefest among the contemporary civil codifications. Although Jovan Hadžić was accused for merging and omitting some ABGB articles, he willingly made a shorter but still quite comprehensive code. He eliminated certain complex institutions, unsuitable for the undeveloped Serbian society of that time. He also added a lot, such as an entire chapter dedicated to the most sensitive customary type of joint family organization (Slavic zadruga) and other original additions. Consequently it is not a "condensed edition" of the ABGB, but rather its modification in accordance with society's need.

\subsubsection{Introductory chapter}

The SCC begins with another additional material that does not exist in the ABGB. It has 35 introductory articles, as opposed to only 14 in the ABGB. Although the first 14 articles are mostly similar to the $\mathrm{ABGB}$, the rest are very distinctive and unique, as they treats general principles of law and justice. This part of the introductory chapter covers both private law and political significance: some liberal principles and political rights such due process of law, inalienability of natural rights, the prohibition of slavery, the principle of equality, etc. were skillfully incorporated so that they served to clarify the elementary principles of private law. Such double-faceted introductory part makes the SCC not only dissimilar to the ABGB but quite unique in comparative legal history. ${ }^{37}$

\subsubsection{Structure}

The SCC generally follows the institutional system like the ABGB. However, Hadžić remodeled and rearranged the ABGB structure in some aspects. For example Hadžić puts donation in the case of death within the norms regarding the laws of inheritance (Art. 469), while the ABGB regulates it in the chapter on gifts $(\S 603)$. In the contract of sale some articles from the ABGB are combined into a single article $(\S 1080$ and 1081 are covered by SCC Art. 667), some are abbreviated, others are omitted ( $\$ 1073$ and 1074). In some places new norms are inserted (Art. 672 and 675), while in others the sequence of norms was changed. Most

\footnotetext{
37 S. Avramović (2017), 421-428.
} 
modifications were due to a tendency to abbreviate the text and make the SCC shorter. 38

\subsubsection{Form of the SCC norms}

Although Hadžić was a well-educated lawyer with excellent knowledge of comparative law, he evidently tended to direct the codification at the users, the population of the undeveloped country of Serbia. He wanted to offer a popular code, comprehensible to the average citizen and peasant. Therefore he often shaped norms of the SCC in a form of examples, rather than as abstract legal rules. For example he defines possessio by words: "He who holds a thing in his hands has possession..." (Art. 223). The corporal thing is explained as "If things are perceptible by sight and affect other senses, they are called corporeal things, such as land, house, vineyard, orchard, tool, fruit, clothing, etc.", in contrast to ABGB $\$ 292$ which offers a definition from classical Roman law ("Corporeal property is that which is tangible"). When he speaks about immovable he again uses language of examples: "such as a house, field, pasture, vineyard, orchard, etc." (Art.293 and 295). This is all quite different from the formulations in the ABGB, with sophisticated juristic definitions.

\subsubsection{Differences in content between the $S C C$ and $A B G B$}

In terms of content the SCC is much more different from its model code then the DCC. It is primarily a consequence of the different historical background, legal sources and specific social circumstances.

\subsubsection{The CC influence}

The SCC did not follow entirely the ABGB model, as it additionally accepted certain solutions from the $\mathrm{CC}$ (which was the initial desired donor code in Serbia). The only issue is whether the transfer came from the original or through the ABGB, as Franz von Zeiller surely followed the $C C$ in part. ${ }^{39}$ Therefore some similar norms can be found in the $C C$, $\mathrm{ABGB}$ and SCC, particularly in the introductory sections. A striking example are ABGB $\S 12$ and SCC Art.11 which correspond fully to CC Art.5, aimed at eliminating the common law tradition of precedents and promoting a law-based system. There are many more examples of similar norms in the SCC and CC. ${ }^{40}$ After the amendments of 1864 the Serbian civil law gradually moved closer to the French legal tradition.

38 S. Aličić, "Sistematika odredbi o obligacionim odnosima u Srpskom građanskom zakoniku u svetlu sistematike Justinijanovih Institucija", Zbornik Pravnog fakulteta u Novom Sadu 38/2004, 395-406. S. Avramović (2017), 431.

39 M. Reiner, "Franz von Zeiller und der Code Civil Napoleons", Mélanges Fritz Sturm (eds. J.-F. Gerkens et al.), I, Université de Liège, Liège 1999, 867-879.

40 B.T. Blagojević, "Uticaj francuskog Građanskog zakonika na srbijanski Građanski zakonik", Pravna misao 1940, 477-534; B. T. Blagojević, "L'influence du 


\subsubsection{The Roman law reception}

It was observed long ago that Hadžić introduced Roman law into Serbia thanks to the ABGB. However Serbian medieval law was influenced by Roman-Byzantine law which mostly vanished during the Ottoman rule, except in the Serbian Orthodox Church. So, as for the Roman law influence on the SCC the issue is whether it was transferred in $19^{\text {th }}$ century Serbia via ABGB, through the medieval tradition or as a direct borrowing by Hadžić. The perception of the ABGB as the sole intermediary of Roman law reception in Serbia was firstly questioned by prominent Serbian legal scholar Slobodan Jovanović. He stated that the solutions on the communitarian family type of zadruga were based on perceptions deriving from Roman law independently of the ABGB.$^{41}$ Later contributions on many other legal institutions confirmed the view that Hadžić often opted for the direct reception of Roman law without ABGB interference (findings by Danilović, Malenica, Aličić, Knežić, Polojac, Vuletić, etc.). ${ }^{42}$ Therefore today it seems undisputable that the Roman law influence came both through the ABGB and as a direct transfer by the legislator.

\subsubsection{Role of customary law}

During the Ottoman rule customary law was the sole legal source. It became one of the chief problems for the legislator of the SCC. Hadžić was on one side strongly criticized for disregarding customary law and his tendency to modernize Serbian law too early. Prince Miloš also wanted to have a codification predominantly rooted in customary law. Hadžić was also accused of wanting to destroy old form of communitarian family life and property in zadruga as he favored a kind of co-ownership dressed in Roman law colors instead of collective ownership, etc. He also wanted to introduce equality between sons and daughters in inheritance law and promote a better legal position of woman, but his solutions were not accepted by the State Council and the old discriminatory norms remained in the SCC. Nevertheless, Hadžić was blamed for that failure and "was cursed by the women on the city streets". Otherwise, he tried to keep the customary law whenever it was acceptable. He succeeded in creating

Code civil sur l'elaboration du Code civil serbe", Revue internationale de droit comparé 6(4)/1954, 733-743; S. Avramović (2017), 433-435.

41 S. Jovanović, 48.

42 These and other contributions with similar approach appeared in the commemorative collections of papers: M. Jovičić (ur.), 150 godina od donošenja Srpskog građanskog zakonika 1844-1994, SANU, Beograd 1996; R. B. Kovačević Kuštrimović (ur.), 150 godina od donošenja Srpskog građanskog zakonika 1844-1994, Pravni fakultet Univerziteta u Nišu, Niš 1995; M. Polojac, Z. S. Mirković, M. Đurđević (ur.), Srpski građanski zakonik 170 godina, Pravni fakultet u Beogradu, Beograd 2014. S. Avramović (2017), 436-440. 
quite a modern civil codification, keeping to some extent unavoidable elements of customary law that were deeply rooted in the national identity. ${ }^{43}$

\subsubsection{Church law impact}

The SCC recognizes church marriage as the only valid form and it was a contract stipulated by the priest. Marriage law was mostly regulated according to medieval Nomocanon of St. Sava and other church law sources. Hadžić was well aware that there was no chance to intervene in family law due to strong historical influence of the Church, so he decided to keep the competence in marriage law within the secular legislation, but that the norms should be in accordance with Church law principles. Differences between provisions in the SCC and ABGB are clearly visible in marriage and family relationships, in the definition and concept of marriage, regulation of betrothal, kinship, adoption, etc. ${ }^{44}$ The presence of so many norms related to Church law produce in consequence a sharp discrepancy between the donor and recipient code, as family law was the most resistant to changes in the SCC.

\subsubsection{Sharia and Ottoman law remnants}

Several centuries of the Ottoman rule in Serbia had left traces at all levels, including the legal heritage. Sharia law was applied alongside domestic customary law. Some Sharia institutions, particularly those concerning landed property, became part of everyday life in the $19^{\text {th }}$ century. The SCC tried to introduce the concept of land register books, like in Austria. Also, acquisition of property was connected both to titulus (usually a contract) and modus acquirendi (an additional formality), like in Roman and Austrian law. However, the new land register books were not established for decades, and the Sharia institution of the tapu (title deed) system remained evidence of property for a long time. So-called intabulation books for the registration of hypothec and other similar rights persisted as well. A specific type of landed property named miljak in Serbian (probably as a derivate from Turkish milk, mulk) was accepted by the SCC as a kind of unlimited rights over immovable property. The SCC retained several other less-frequent Ottoman institutions. ${ }^{45}$ Although Hadžic believed that the SCC would modernize the landed property evidence by borrowing the land register books from the Austrian tradition, the Sharia remains stayed alive for many decades.

43 For more details see S. Avramović (2017), 441-447.

44 See more in ibid., 449-451.

45 Ibid., 452-457. 


\subsubsection{Introduction of national legal terms}

Hadžić was faced with relatively undeveloped legal national terminology and he had to offer new terms for modern legal institutions that were sometimes unknown to the general population. He also simplified complicated German linguistic structures and constructions, trying to make their sense clearer to the public. He frequently used synonyms and doublets to be more intelligible to his readers, for example as in Art. 424: "A testament, will, or last wish is the disposition by an individual of his entire property or part of it in case of death". He also used Latin terms which he transformed into Serbian (such as fideikomis, legat, sekvestar, tutor, servituti, etc.) and contributed a lot to the development of Serbian legal terminology. In that way the SCC performed a type of educational mission in the modernization of the national legal language. Such a task was not necessary when the DCC was drafted.

\section{BEFORE CONCLUSION: WHAT DOES MIXED LEGAL SYSTEM MEAN?}

A mere fifty years ago, mixed systems were treated as legal aberrations and were scarcely discussed. The focus was on a coherent ordering of les grands systèmes, and no space was found in taxonomies for composites and hybrids. ${ }^{46}$ This is why we are still trying to find the place of the DCC and SCC among some of the "great legal systems" and to declare them offspring of either the CC or the ABGB. Fortunately, as Palmer says, there is growing awareness that mixed systems, whether restrictively or expansively defined, are a widespread and recurrent reality. However, at the same time Palmer and other scholars are trying to make a new taxonomy of mixed legal systems by using the term "mixed jurisdiction" (usually covering a combination of common and civil law as a new, "third family"). The new approach to comparative law started to complicate the notion of mixed legal systems and therefore there is no consensus among legal comparatists on its meaning.

According to some research "mixed systems" appear in ten categories: mixes of civil law and common law (3.47\% of the world population); civil law and customary law (28.54\%); civil law and Muslim law (3.14\%); common law and customary law (2.94); common law and Muslim law (5.25\%), civil law, Muslim law and customary law (3.62\%); common law, Muslim law and customary law (19.17\%); civil law, common law and customary law $(0.8 \%)$; common law, Muslim law and

46 V. V. Palmer, "Mixed Legal Systems", The Cambridge Companion to Comparative Law (ed. M. Bussani, U. Mattei), Cambridge University Press, Cambridge 2012, 368. 
civil law $(0.23 \%)$; and of civil law, common law and Talmudic law $(0.09 \%)$. The number of jurisdictions that fall into the "mixed systems with civil law" category are 65 (19.12\% of the world's legal systems), "mixed systems with common law" are 53 (15.59\%), "mixed systems with customary law" are $54(15.88 \%)$ and "mixed systems with Muslim law" are $33(9.70 \%) .{ }^{47}$

However, it seems that not a single legal system can evade legal transplants: it is only a matter of quantity. Even the parent legal systems and fundamental, original donor codes like the $\mathrm{CC}$ or $\mathrm{ABGB}$ were also influenced by different sources, at least by Roman law, ${ }^{48}$ their own customs, natural law principles, etc. Often a variety of sources are perplexed as external factors of influence. Basically every legal system and every codification is more or less a type of mixture of different legal identities. The prevailing component merely shapes its main facet. Consequently, hybridity is a universal fact. ${ }^{49}$ Therefore existing taxonomies lose their significance and applicability as there are hundreds of diverse mixed legal systems. Some classifications might be relevant when the codification/legal system absorbs a few ingredients, but often there are many more components included and many legal traditions are perplexing. Also, the resulting blend should not necessarily carry a pejorative meaning of mish-mash legal product. Therefore mixture of legal identities should be a more relaxing and less demanding term, as it does not imply a (mixed) system and it is an open-ended concept. It enables comparisons between different codifications and legal traditions, avoiding definitions, taxonomies and classifications.

\section{CONCLUSION}

In chronological terms, the DCC of 1838 and SCC of 1844 sit between the first and second generation of modern civil codifications. They appeared significantly earlier than the codes of bigger, more developed and historically less turbulent countries. They followed the decisive phases in the formation of their nation-states. The two civil codes were regarded as a sign of national maturity, a token of independence and part of the nation-building process. They reflect a kind of legal nationalism, regardless of the fact that they basically borrowed two foreign civil

47 E. Örücü, "What is a Mixed Legal System: Exclusion or Expansion?", Electronic Journal of Comparative Law 12(1)/2008, 4-5.

48 Just a tiny observation that Roman law itself was in a sense composite legal system as it absorbed ius gentium into its own body of ius civile.

49 V. V. Palmer, "Mixed Legal Systems... and the Myth of Pure Laws", Louisiana Law Review 67(4)/2007, 1208-1211. 
codifications. Despite the authority of the $\mathrm{CC}$ and the ABGB, the main issue, both in the Netherlands and Serbia, was to what degree to combine the donor code with inherited legal traditions. In both cases family law was the most sensitive ground and resistant to innovations.

Nevertheless both the DCC and SCC are more or less considered a copy of their prototype codifications, the extensive analysis has shown that they diverge largely from the donor codes in form, structure and content. Both the DCC and SCC combined the legal tradition of the donor country with at least three or more legal traditions, or parts thereof. They could be quite numerous and heterogeneous, as in case of the SCC (national custom, Church law, Roman law, Code civil, Sharia rules). Consequently the SCC differs more from its respective donor code than the DCC does. Independently of how many ingredients the legal mixture contains, they could operate simultaneously within a single system more or less successfully, depending on cleverness of the drafters and compliance of the policy makers. A hybrid legal formation such as the SCC escapes taxonomies as it cannot be included in any existing classification of mixed legal systems. When the codification is so unique, albeit the given donor code is basically predominant, the most adequate description deserves a less formal and less demanding label: a mixture of legal identities. The persistence and deep traces that the DCC and the SCC have left in the legal systems of the two countries attest that such a mixture is not necessarily an unsuitable odd legal mish-mash.

Last but not least, the SCC drafting history confirms Watson's thesis that even chance and coincidence can sometimes cause legal transplants. The poor knowledge of the French language by the Serbian drafters provided an opportunity for the Austrian model to become the chief source of the Serbian private law codification, within a specific mixture of diverse legal identities.

\section{REFERENCES}

Aličić, S., "Sistematika odredbi o obligacionim odnosima u Srpskom građanskom zakoniku u svetlu sistematike Justinijanovih Institucija", Zbornik Pravnog fakulteta u Novom Sadu 38/2004.

Aranđelović, D., Rasprave iz privatnog prava, Beograd 1913.

Aranđelović, D., "O izmeni našeg Građanskog zakonika", Branič 9(1)/ 1904.

Asser, C., Het Nederlandsch Burgerlijk Wetboek vergeleken met het Wetboek Napoleon, De Gebroeders van Cleef, 's Gravenhage 1838. 
Avramović, S., "The Serbian Civil Code of 1844: a Battleground of Legal Traditions", Konflikt und Koexistenz. Die Rechtsordnungen im 19. und 20. Jahrhundert, Band II - Serbien, Bosnien-Herzegowina, Albanien (Hrsg. Th. Simon), Max-Planck-Institut für europäische Rechtsgeschichte, Frankfurt am Main 2017.

Avramović, S., "Sretenjski ustav - 175 godina posle", Anali Pravnog fakulteta u Beogradu 1/2010.

Avramović, S., Stanimirović, V., Uporedna pravna tradicija, Pravni fakultet Univerziteta u Beogradu, Beograd 2015.

Blagojević, B. T., "Uticaj francuskog Građanskog zakonika na srbijanski Građanski zakonik", Pravna misao 1940.

Blagojević, B. T., "L'influence du Code civil sur l'elaboration du Code civil serbe", Revue internationale de droit comparé 6(4)/1954.

Brauneder, W., "Europas erste Privatrechtskodifikation: Das Galizische bürgerliche Gesetzbuch", Naturrecht und Privatrechtskodifikation (Hrsg. H. Barta, R. Palme, W. Ingenhaeft), Wien 1999.

Brauneder, W., "The 'First' European Codification of Private Law: The ABGB", Zbornik Pravnog fakulteta u Zagrebu 63(5-6)/2013.

Breneselović, L. (ed.), Spomenica Valtazara Bogišića, I-II, Službeni glasnik, Beograd 2011.

Chorus, J., Gerver, P-H., Hondius, E., Introduction to Dutch Law, Kluwer Law International, Alphen aan den Rijn 2006.

Feenstra, R., Zimmermann, R. (eds.), Das römisch-holländische Recht: Fortschritte des Zivilrechts im 17. und 18. Jahrhundert, Duncker \& Humblot, Berlin 1992.

Fontein, A., "A Century of Codification in Holland", Journal of Comparative Legislation and International Law 21(3)/1939.

Glen, H. P., Legal Traditions of the World, Oxford University Press, Oxford 2007.

Héroguel, A., Problèmes de traductions dans les droits civils français et néerlandais, L' Harmattan 2000.

Jovanović, S., "Jovan Hadžić", Iz naše istorije i književnosti, Srpska književna zadruga, Beograd 1931.

Jovičić, M. (ur.), 150 godina od donošenja Srpskog građanskog zakonika 1844-1994, SANU, Beograd 1996.

Konstantinović, M., "Jugoslovenski građanski zakonik", Anali Pravnog fakulteta u Beogradu 3-4/1982 (republished from Pravni zbornik $1(2-3) / 1933)$.

Kovačević Kuštrimović, R. B. (ur.), 150 godina od donošenja Srpskog građanskog zakonika 1844-1994, Pravni fakultet Univerziteta u Nišu, Niš 1995. 
Lok, M., van der Burg, M., "The Dutch Case: The Kingdom of Holland and the Imperial Departments", The Napoleonic Empire and the New European Political Culture (eds. M. Broers, P. Hick. A. Guimerá), Palgrave Macmillan, Basingstoke 2012.

Lokin, J., "Die Rezeption des Code Civil in den nördlichen Niederlanden", Zeitschrift fur Europaisches Privatrecht 4/2004.

Luković, M., "Valtazar Bogišić and the General Property Code for the Principality of Montenegro: Domestic and Foreign Associates", Balcanica 39/2008.

Matić, D., Objasnenija Građanskog zakonika za knjaževstvo Srbsko, IIII, Beograd 1850-51.

Meijer, G., Meijer, S. Y. Th., "The Influence of the Code Civil in the Netherlands", European Journal of Law and Economics 14(3)/2002.

Örücü, E., "What is a Mixed Legal System: Exclusion or Expansion?", Electronic Journal of Comparative Law 12(1)/2008.

Palmer, V. V., "Mixed Legal Systems... and the Myth of Pure Laws", Louisiana Law Review 67(4)/2007.

Palmer, V. V., "Mixed Legal Systems", The Cambridge Companion to Comparative Law (ed. M. Bussani, U. Mattei), Cambridge University Press, Cambridge 2012.

Polojac, M., Mirković, Z. S., Đurđević, M., (ur.), Srpski građanski zakonik 170 godina, Pravni fakultet u Beogradu, Beograd 2014.

Ranke, L., A History of Serbia and the Serbian Revolution (translated by A. Kerr), J. Murray, London 1847.

Reiner, M., "Franz von Zeiller und der Code Civil Napoleons", Mélanges Fritz Sturm (eds. J.-F. Gerkens et al.), I, Université de Liège, Liège 1999.

Robinson, O. F. et al., European Legal History: Sources and Institutions, Oxford University Press, Oxford 2005.

Šeroglić, P., "Pregled Zakonika Građanskog za knjaževstvo Serbiju, 25. marta 1844. obnarodovanog", Bačka vila 4/1845.

Van den Bergh, G. C. J. J., Die holländische elegante Schule: Ein Beitrag zur Geschichte von Humanismus und Rechtswissenschaft in den Niederlanden 1500-1800, Klostermann, Frankfurt 2002.

Van der Burg, M., "Cultural and Legal Transfer in Napoleonic Europe: Codification of Dutch Civil Law as a Cross-national Process", Comparative Legal History 3(1)/2015.

Van Kan, J., "Het Burgerlijk Wetboek en de Code Civil", Gedenkboek Burgerlijk Wetboek 1838-1938 (ed. P. Scholten, E. M. Meijers), Tjeenk Willink, Zwolle 1938.

Watson, A., Legal Transplants - An Approach to Comparative Law, The University of Georgia Press, Athens, Georgia 1993. 
Zimmermann, R., The Law of Obligations: Roman Foundations of the Civilian Tradition, Oxford University Press, Oxford 1996.

Zweigert, K., Kötz, H., An Introduction to Comparative Law (translated by T. Weir), Clarendon Press, Oxford 1998.

Article history:

Received: 30. 10. 2018.

Accepted: 13. 12. 2018. 